\title{
Identifying lifestyles of Kosovo beer consummers
}

\author{
Arsim Begunca ${ }^{1}$,
}

\begin{abstract}
It is generally known that the business of enterprises nowadays takes place in a very dynamic environment and in terms of a very tough competition that exceeds the boundaries of a country due to unprecedented business internationalization. Therefore, to survive and develop a successful business in a blur and unclear environment many enterprises develop their business by the marketing concept, according to which the market segmentation is done through various methods using different variables. One of variables used in segmentation is the lifestyle, which falls within the psychographic variables. This study aims to identify the lifestyles of beer consumers in Kosovo, through constructing a valuable and reliable instrument in order to profiling consumers. By identifying lifestyles, the industry is able to use these data (information) to identify and understand target markets, having available more information about things the consumers value, their activities and what are the basic personal features they have. If target markets are understood a quality product or service can be provided which will highly satisfy consumer needs that affect growth of business activity at the same time.

The paper-study aiming to achieve objectives is organized in five chapters:

Preface; 2. Introduction 3.Research methodology; 4. Data Analysis; 5. Conclusions, implications, study limitations and suggestions for future studies.
\end{abstract}

Key Words: lifestyle, trade, consumer satisfaction, market, quality.

\section{Introduction}

\subsection{Knowledge regarding lifestyle}

Expression LIFESTYLE is commonly used to categorize people who share same features and beliefs. "Lifestyle" is a concept widely used and accepted in the social sciences, and this expression has emerged in psychology and sociology literature in the last three decades. (Horley, Caroll \& Little,1998).

The concept of lifestyle is useful not only for the traders to mark different segments, but it is also for the people to understand themselves in terms of how they behave and what do they value.

Research suggests that the recognition of people's lifestyle can allow marketers and researchers to predict their behavior; in particular purchasing behavior is one of the most important tasks for scientists in these fields of research. Purchasing behavior reflects consumer values that best show their lifestyle. Therefore researchers and traders are interested in following the lifestyle and value segmentation studies. (Kahle \& Kennedy, 1989).

Since the early use by Lazer in 1963 information over lifestyle analyzes has become very popular tool in Marketing Management in decision making. Using the values and lifestyle as criteria for segmentation has consistently raised hopes that they explain more the 
different behaviors (actions) observed, than the demographic and social-economic variables.

Because consumer lifestyle values and features provide a better view of the market and another portrait of consumer's life and demands, they reach the requirements of management practices for sophisticated and acting increase of the marketing information.(Wasner \& Wedlle:cit.Talha Harcar dhe Erdenar Kaynak,2004).

Rona Ostrow and Sweetman R.Smith Marketing Dictionary describes lifestyle as characteristical way of behavior centered around activities, interests, opinions, positions and demographic characteristics that distinguish one segment of population from another. Consumer lifestyle is seen as the sum of his interactions with his environment.

Lifestyle studies are components of broad concepts of behavior called psychografy. Oxford English Dictionary claims that early use of the term "lifestyle " is made by Alfred Adler, psychologist, who used it in 1929 to present the basic character that was established in early childhood that governs ones reactions and behaviors. Notion of lifestyle appeared for the first time in Max Weber's work (1958), where he perceives the lifestyle as a means of identifying the distinct status across social groups. A similar view can be found in Veblen's conspicuous consumption, which is mainly motivated by the desire for social prestige (Katona, 1965). The modern theory of consumer behavior defines lifestyle as a summary built to reflect the patterns according to which man lives and spends his time and money (Engel et al.1995).

Lifestyle study is interdisciplinary. It is supported by different disciplines such as anthropology, psychology, sociology and economics. Marketing uses these eclectic ways for segmentation, marking and positioning that form the core of marketing strategy.

\subsection{Problem defination and formulation}

Beer market presents a relatively widespread market and with a trend of increasing its consumption

from one year to another. Therefore for companies that deal with production also those who only deal with selling this product, the need for identifying consumer's needs for this article is presented. It is well known that the focus of every enterprise that is oriented towards marketing concept is the customer and his requirements and the whole activity of these companies is focused on providing products or services that satisfy these customer needs. To achieve these objectives the company uses market segmentation as the most efficient approach for a better fulfillment of customer needs and requirements. Within the variables used for market segmentation there are also psychographic variables, in which consumer lifestyle is included. With this paper/study, we intend to identify beer consumer lifestyles as one of psychographic variables to be used for efficient beer market segmentation in Kosovo.

By segmenting beer consumers under lifestyles we get information about activities, interests, opinions, positions, values and demographic characteristics that distinguish one consumer segment from another. 


\subsection{Purpose of the study}

The purpose of this study is to identify the beer consumer lifestyles in Kosovo. In particular the

study was designed to construct lifestyle instruments and their use in detecting patterns of current beer consumer lifestyles.

Main cause for beer consumer segmentation based on lifestyles is that market-related decisions would be more effective and provide detailed information regarding this industry customers. By identifying lifestyles the industry is able to use these data ( information ) to identify and understand the target markets, having available more information about what are the things they value, their activities and what are the basic personal characteristics they have.

The study pretends that the industrial market can be segmented by the lifestyle and if the industry can understand its customer 's and its lifestyle then it can create a high degree of customer satisfaction. So eventually by identifying beer consumer's lifestyle we will provide a good analytic base for beer market segmentation, better positioning of the product on the market, promotion and a more effective advertisement.

\subsection{Study hypotheses}

After a comprehensive literature review of values and lifestyle, several hypotheses have been developed in order to test the differences between identified lifestyles.

H1: Most of the beer is consumed by the group of sport-recreational-entertainment orientated consumers.

H2: Women who consume beer mostly belong to sport-recreational-entertainment orientated consumers.

H3: Consumers belonging to traditional-family orientated segment mostly consume beer in their home near their families.

H4: There are lifestyle differences of beer consumers depending of gender.

H5: There are lifestyle differences depending on age.

\subsection{Measurement systems in lifestyle studies}

Four classic measurement systems are known that are related to lifestyle studies, which are: Rokeach Value Survey(RVS); List of Values(LOV); Attitudes Interests and Opinions(AIO) and Values, Attitudes and Lifestyle System(VALS). Since we have taken List of Values (LOV) as segmentation basis according to Lifestyle, further down we will describe only this instrument in measuring lifestyles.

\subsubsection{List of Values -(LOV)}

List of Values (LOV) has been developed by researchers in the Analytical Research Center, University of Michigan (Kahle, 1983; Veroff, Douvan \& Kulka , 1981) . Construction of LOV is based on the theoretical foundations on values from works of Feather (1974), Maslow (1954) and Rokeach (1973). List of values includes a list of nine values. Responders to List of Values were requested to evaluate each of the nine values and show below the most important one. Review by Kahle, Homer and Beatty found that the LOV instruments have been adopted and replicated in different areas, and that 
these research findings provide validation for LOV. Method of testing and retesting reliability is used to ensure the reliability of the issue of LOV ( Beatty, Kahle, Homer \& Misra, 1985).

Table 1.1. The questionnaire form for the LOV .

Below is a list of things that some people seek or want from life. Please study the list carefully and then rank each thing how much it is important in your life, where $1=$ not at all important and 9 = very important

-A sense of belonging ( to be accepted and needed by your family, friends and community)

-Excitement (in experiencing incentive and emotion )

- Warm relationship with others ( to have a close relationship and close friendship )

- Self - fulfillment ( find peace of mind and using your talents as best you could ).

- To be respected ( admired by others and accept assessments ) .

- Recreation (have fun) and experiencing life (make life happy and enjoyable )

-Safety ( to be protected and guarded against attacks) .

-Self - respect (being proud of yourself and confident with who you are ).

- The sense of achievement ( fulfillment ) ( to succeed in what you want to do ).

Source: Kable \& Kennedy (1989). pg.8.

Kahle and Kennedy (1989) noted that at least four different methods of data analysis can be used to analyze the LOV data. These methods are nominal analysis, regression analysis, analysis of cause and segmentation analysis, which provide more information from the given data than traditional methods. One of the studies carried out by LOV as part of the study instruments, which it has been designed to forecast different styles of leissure travelling during free time (vacation) (Madrigal,1995). "Cross-National Consumer Psychographics"(Kahle,2000) is a summary of eight studies, which compares different aspects of psychographic consumer data at national and cross-cultural level. According to Kahle (2000) LOV is an instrument which can be used to understand the cultural aspects of consumers based on their social value.

\section{Research methodology}

\subsection{Research method}

This research intends to segmentize beer consumers by their lifestyle testing proposed assumptions/ hypothesis based on the existing theory. Quantitative approach is used more in this study than the qualitative approach. Quantitative approach is more suitable to test and evaluate the assumptions and to follow standard procedures which 
are strict in the used instruments and allow the statistical data analysis to identify relevant information related to beer consumer lifestyles in Kosovo.

The face to face survey with self-administered questionnaire was adopted in this study as a data collecting method. Alreck and Settle (1995) pointed out that self-administered questionnaires are an excellent way to ask responders and provide information, provided by an expert and when the appropriate instrument has been used.

\subsection{Justification of research methods}

Research methods generally fall into two types, quantitative (quantity) and qualitative (quality).All these methods provide different ways of collecting and interpreting information or survey data. Veal (1997) pointed out that the relative merits of quantitative and qualitative research are debated in the literature and any method generally is considered valued or not valued, than wrong or right. For example, it is proved that qualitative methods are shifting of the "old" quantitative approach (Denzin \& Lincoln, 1994), whereas researches without quantitative approach/access are not considered scientific (Levine, 1993).

This study aims to segmentize beer consumers according to their lifestyles by testing proposed hypotheses based on existing theory. Quantitative approach is used more than qualitative approach in this study. Quantitative approach is more suitable to test and evaluate hypotheses and follow the standard procedures that are rigorous in the used instruments and allow statistical data analysis to identify relevant information related to the beer consumer lifestyle in Kosovo.

In this study the face-to-face survey with self-administered questionnaire was adopted as a method of data collection. Alreck and Settle (1995) indicated that self -management surveys are a great way to ask respondents and provide information provided by an expert and when appropriate instrument is used.

Taking into consideration the strength and limitations of the research methods, the cause of this study and the circumstances of the study where numerous questions should be implemented; it is very clear that the application of a direct research through selfadministered questionnaire is suitable for gathering data for this study.

Primary data on this topic are provided through various survey respondents in Kosovo Through a self administered questionnaire we have surveyed a total of 182 responders, where the information obtained from these surveys is used as primary data and presents the essence of research. The questionnaire consists of 34 questions; the series of questions are designed to have a range of responses focusing on the same general topic. In short questionnaire includes 21 questions for beer consumption section, two questions for the values section, a question for hobbies and 10 questions on demographic characteristics section.

Values component is adopted from studying LOV(Kahle,1983,Veroff,Douvan and Kulke,1981). LOV scale is used in several studies on lifestyle and these studies have shown that the LOV scale is good to forecast customer behavior and consumer segmentation based on different value status. There are two questions in questionnaire at the values section. 


\subsection{Sample selection}

A self-administered questionnaire is used in this study that is directly distributed by the researcher in randomly selected sample. The study uses one scale sampling method. Therefore, Kosovo residents of ages 18 and up have been randomly selected in conducting this study.

2.5 Methods of analysis

Program named Statistical Package for Social Science (SPSS version 19) is used for data analysis. This study used factorial analysis, independent samples, T-test, one way between groups ANOVA and K-means cluster analysis.

\subsection{Data Analysis}

\subsection{Factor Analysis}

Factor analysis is applied in this study to reduce the number of variables, in order to make the study interpreted easier. Twenty- three issues of " consumption of beer " section and eleven issue of "values and hobbies " have been subject to factor analysis in order to reduce the large number of variables in a smaller community of fundamental factors .Before applying the PCA - Principal Components Analysis data adequacy of factor analysis is assessed or reviewed. Any issues in correlation matrix having a coefficient of less than 0.3 in any other matter were removed. Also the commonalities table is examined and any issue with less than 0.50 was also removed as a low value of commonalities, since they show that these variables don't have any relation to other variables in the community.(Field,2005;Tabachnick \& Fidell,2000).

Factor analysis was performed using the Principal Component Analysis-PCA with orthogonal rotation

(varimax). Orthogonal rotation was chosen because the resulting factors will be used in subsequent statistical analysis and this approach minimizes collinearity (Hair,Anderson,Totham \& Black,1998). Two sources of information were examined in order to determine the number of factors that will be elected, Eigenvalue size and Eigenvalue screeplot. Only factors with an Eigenvalue of 1 or more are taken into account and Screeplot diagram is checked for the information of the number of factors. Three factors have been derived based on these sources of information on the consumption of beer section, whereas for "Values and Hobbies" section one factor has been derived. Furthermore, individual issues and factor loadings are inspected. In the final selection 7 out of 23 cases of consumption of beer and 9 out of 11 cases of values and hobbies that have a factor loading 0.4 and over in one factor have been held (Field, 2005) and these issues have been reduced to four principal factors.

Kaiser-Meyer-Olkin Sample Suitability measurement unit which provides measurement unit in quantifying of the inter-correlation scale through variables and appropriateness of factor analysis, for 'beer consumption' section is 0.602 , and for the section of 'values and hobbies' is 0.687, exceeding the recommended value of 0.6 (Coakes \& Steed, 1999; Kaiser.1970,1974).

Bartlett's Test of Sphericity reached statistical significance $(\mathrm{p}=0.00)$, supporting the factorability of the correlation matrix for factor analysis.

At 'beer consumption' 3 selected factors with Eigenvalue factor exceeding 1, explain $70.88 \%$ of the variance, whereas factor chosen at 'values and hobbies' explains $59.80 \%$ 
of variance. Table 3.1 presents the results of the factor analysis section of "beer consumption " and "values and hobbies" section.

The reliability analysis was conducted to test the internal consistency of each factor provided by factor analysis. Cronbach Alfa coefficient is one of the indicators that usually is used mostly in the internal sustainability (Coakes \& Steed,1999;Pallant,2001) and normally is recommended to be above 0.6 in research studies (Hair , Anderson , Tatham \& Black , 1998). All factors obtained by factor analysis show Cronbach Alfa coefficient to be above 0.6.

Table 3.1 Factors derived from factor analysis

\begin{tabular}{lllll}
\hline & \multicolumn{3}{l}{ Components } & \\
\cline { 2 - 4 } Issues & 1 & 2 & 3 & \\
\hline Eigenvalue & 3.008 & 1.240 & 1.060 & 5.382 \\
\hline Cronbach Alfa coefficient & 0.809 & 0.627 & 0.602 & 0.724 \\
\hline Factor 1 & & & & \\
How many bottles of beer you drank last week & 0.891 & & \\
How many bottles of beer you drank last month & 0.822 & & \\
How strong you like your beer & 0.583 & & & \\
Factor 2 & & & & \\
Do you drink beer at home & & 0.878 & & \\
What beer you use in your home & & 0.837 & & \\
Factor 3 & & & 0.732 & \\
Season when you drink mostly & & & 0.705 & \\
Which is your favorite wrapping/packaging & & & \\
Factor 4 & & & \\
What is your hobby & & & 0.781 \\
What things have greater importance... & & & 0.734 \\
The sense of belonging & & & 0.496 \\
Warm relationship with others & & & 0.651 \\
Self-fulfillment & & & 0.749 \\
To be respected & & & \\
Safety/Security & & & \\
Self respect & & & \\
Feeling/sense of achievement & & & \\
\hline
\end{tabular}

\subsection{Cluster Analysis}

Cluster analysis is one of statistical analysis that is used in many segmentation studies in defining groups. There are two main subdivisions of clustering procedures, when the number of clusters is default/determined then K-means Cluster method is used and hierarchy cluster analysis is used when the number of clusters is not predetermined. K - Means cluster analysis is used to identify relatively homogeneous groups of cases based on selected characteristics for this study.K - Means cluster analysis procedure requires that cluster number should be specified in order to continue with the 
analysis. K-Means attempts to to identify relatively homogeneous groups of cases based on selected characteristics using an algorithm that can manipulate large numbers of cases. The study initially speculated that there are three to five segments of consumer lifestyles that should be explored. Of the total number of 182 responders- consumers of beer, for selecting of three clusters the number of cases (respondents) was 68, 34 and 80. For selection of four clusters number of cases was $68,56,14$ and 48 ; whereas for selection of five clusters the number of cases was 54,44,8,36 and 40 .

From case analysis of four and five clusters there are many matching features across groups, but at three clusters selection there are less matching features across groups. For this reason and for the purposes of interpretation this study has used the three cluster selection in order of grouping beer consumer respondents. In ANOVA table we presented all cases used in cluster analysis.

Table 3.2 ANOVA Table for three chosen clusters

\begin{tabular}{llll}
\hline Factors & DF & F & significant \\
\hline Beer consumption & & & \\
Amount of consumption in last week & 2 & 5.814 & 0.004 \\
Amount of consumption in last month & 2 & 3.363 & 0.390 \\
Do you drink beer at home & 2 & 0.358 & 0.700 \\
Season when you drink beer the most & 2 & 54.755 & 0.000 \\
Which wrapping you prefer & 2 & 1.116 & 0.332 \\
What beer you use in your home & 2 & 2.525 & 0.086 \\
How strong you like your beer & 2 & 0.545 & 0.582 \\
\hline Values and hobbies & & & \\
What is your hobby & 2 & 6.801 & 0.002 \\
What things have greater importance & & & \\
In your daily life & & & \\
& 2 & 157.687 & 0.000 \\
Sense of belonging & 2 & 30.045 & 0.000 \\
Warm relationship with others & 2 & 9.798 & 0.000 \\
Self fulfillment & 2 & 4.674 & 0.120 \\
To be respected & 2 & 2.895 & 0.061 \\
Safety/Security & 2 & 31.684 & 0.000 \\
Selfrespect & 2 & 6.663 & 0.002 \\
Sense/feeling Achievement & 2 & 3.627 & 0.031 \\
\hline
\end{tabular}

Using membership information by cluster analysis, frequency analysis was conducted to provide an overview for each cluster .

Cluster or segment 1. This cluster represents $37.36 \%$ of interviewed responders, that is the second cluster from the number of responders throughout three chosen clusters. On the question regarding values where responders had to determine over one of values that are most important on everyday life, in this cluster we have a compact sequence where $100 \%$ of respondents chose the value " recreation and enjoyment of life " ; whereas at 
nine point scaling by Likert's scale this issue has the highest average ranked on 8.76. Also responders in this cluster as their favorite hobby mention sports with $61.8 \%$. From this data we can see that this group is mostly interested in entertainment and sports so it is named " sports entertainment- oriented cluster."

Cluster or segment 2. This cluster is formed from 34 responders and represents 18.68\% of interviewed responders, is also the smallest cluster from three clusters. On question about values in choosing one of values that is most important in everyday life, the security value with $64.7 \%$ and sense of belonging with $17.6 \%$ make the most importance for responders of this group. Whereas at nine point scaling by Likert's scale this security/safety issue again with average of 8.41 and sense of belonging with 8.00 make the highest ranking.

As far as hobbies we have a wide distribution of responses, which mostly is answered in the " Other " $35.3 \%$ where in this group are included hunting, fishing, etc.After that 'sports' are ranked with $29.4 \%$ and 'meeting friends and comrades' with $23.5 \%$. In examining the responses regarding beer consumption it shows that this group consumes the most beer and most of the three clusters consume Beer of Peja ( $82.4 \%$ ). From these data we can see that this group is more family oriented (sens of belonging) than other groups and more traditional in sense of consuming in percentage mostly local beer. Given everything mentioned above this group was named 'traditionally family oriented cluster' group or shortly ' family-traditionalist'.

Cluster or segment 3; this cluster consists of 80 responders and represents $43.96 \%$ of interviewed responders. This cluster makes the biggest group out of three clusters. In the 'Values' question again most importance in everyday life is given to security/safety with $60 \%$. At nine point scaling value of the security reaches the highest ranking from all clusters with an average of 8.53. Main hobby of responders belonging to this group is " meeting friends and comrades' with 35\% and 'Othe' ( fishing, hunting, etc...) When checking answers regarding beer consumption we can see that responders from this group in highest percentage from all clusters, with 15\%, express their concern that consuming beer affects human health. From these data this group is named 'safety and health oriented cluster'.

Table 3.3 Cluster profiles according to demographic features

\begin{tabular}{|c|c|c|c|c|c|}
\hline \multirow[b]{2}{*}{ Personal features } & \multicolumn{2}{|c|}{ Entertainment and sports } & \multicolumn{2}{|l|}{ Traditional -family } & Security-Health \\
\hline & No. of responders & 68 & No. of responders & 34 & No of responders \\
\hline \multirow[t]{4}{*}{ Age } & $18-25,56(82.4 \%)$ & & $26-35, \quad 10(29.4 \%)$ & & $18-25,3(7.5 \%)$ \\
\hline & $26-35, \quad 10(14.7 \%)$ & & $36-45, \quad 14(41.2 \%)$ & & $26-35,9(22.5 \%)$ \\
\hline & $2(2.9 \%)$ & & $10(29.4 \%)$ & & $36-45,15(37.5 \%$ \\
\hline & & & & & $46+, \quad 13(32.5 \%)$ \\
\hline \multirow[t]{2}{*}{ Gender } & Males $46(67.6 \%)$ & & Males $30(88.2 \%)$ & & Males $70(87.5 \%)$ \\
\hline & Females $22(32.4 \%$ & & Females $4(11.8 \%)$ & & Females $10(12.5 \%)$ \\
\hline \multirow[t]{2}{*}{ Education } & High school $26(38$ & $\%)$ & High school 20 (58.\& & & High school $34(42.5 \%)$ \\
\hline & University $42\left(61.8^{\circ}\right.$ & & University $14(41.2 \%$ & & University $46(57.5 \%)$ \\
\hline
\end{tabular}




\begin{tabular}{llll} 
Employment & $\begin{array}{l}\text { Employed 30(44.1\%) } \\
\text { Unemployed 38 (55.9\%) }\end{array}$ & Employed 34(100\%) & $\begin{array}{l}\text { Employed 72(90\%) } \\
\text { Unemployed 80(10\%) }\end{array}$ \\
\hline \multirow{2}{*}{ Civil status } & $\begin{array}{l}\text { Single 62(91.2\%) } \\
\text { Married 6(8.8\%) }\end{array}$ & $\begin{array}{l}\text { Single 4(11.8\%) } \\
\text { Married 30(88.2\%) }\end{array}$ & $\begin{array}{l}\text { Single 12(15\%) } \\
\text { Married 68(85\%) }\end{array}$ \\
\hline \multirow{2}{*}{ No.of family members } & $1-4,26(38.2 \%)$ & $1-4,12(35.3 \%)$ & $1-4,28(35 \%)$ \\
& $5-8,38(55.9 \%)$ & $5-8,16(47.1 \%)$ & $5-8,44(55 \%)$ \\
& $9-12,4(5.9 \%)$ & $9-12,4(11.8 \%)$ & $9-12,2(2.5 \%)$ \\
& & $13+, 2(5.9 \%)$ & $13+, 6(7.5 \%)$ \\
\hline \multirow{2}{*}{ Family income } & $100-300,16(23.5 \%)$ & $100-300,12(35.3 \%)$ & $100-300,28(35 \%)$ \\
& $301-600,34(50 \%)$ & $301-600,8(23.5 \%)$ & $301-600,32(40 \%)$ \\
& $601-1000,14(20.6 \%)$ & $601-1000,10(29.4 \%)$ & $601-1000,14(17.5 \%)$ \\
& $1001+, \quad 4(5.9 \%)$ & $1001+, 4(11.8 \%)$ & $1001+, 6(7.5 \%)$ \\
\hline
\end{tabular}

Table.3.4 Cluster profiles based on hobbies and personal values

\begin{tabular}{|c|c|c|c|}
\hline & Sport-entertainment & Traditional -family & Safety- Health \\
\hline & $\begin{array}{l}\text { No.of responders } \\
68\end{array}$ & $\begin{array}{ll}\text { No.of } & \text { responders } \\
34 & \\
\end{array}$ & $\begin{array}{ll}\text { No.of responders } \\
80\end{array}$ \\
\hline \multicolumn{4}{|l|}{ Hobbies } \\
\hline Sport & $42(61.8 \%)$ & $10(29.4 \%)$ & $15(37.5 \%)$ \\
\hline Music & $18(26.5 \%)$ & $4(11.8 \%)$ & $3(7.5 \%)$ \\
\hline Meeting friends & $2(2.9 \%)$ & $8(23.5 \%)$ & $14(35 \%)$ \\
\hline Other (hunting etc...) & $6(8.8 \%)$ & $12(35.3 \%)$ & $8(20 \%)$ \\
\hline \multicolumn{4}{|l|}{ Personnal values } \\
\hline Most important & Entertainment $(100 \%)$ & Safety $(64.7 \%)$ & Safety $(60 \%)$ \\
\hline Values Ranking & Average & Average & Average \\
\hline Sense of belonging & 6.91 & 8.00 & 7.95 \\
\hline Excitement & 4.88 & 3.53 & 3.57 \\
\hline Warm relationship & 7.21 & 7.82 & 7.65 \\
\hline Self-fulfillment & 6.85 & 7.24 & 7.35 \\
\hline $\begin{array}{l}\text { To be respected } \\
\text { Entertainment and enjoving }\end{array}$ & 7.68 & 8.00 & 7.98 \\
\hline life & 8.76 & 7.71 & 7.40 \\
\hline Safety & 7.59 & 8.41 & 8.53 \\
\hline Self respect & 7.18 & 7.71 & 7.45 \\
\hline Sense of achievement & 7.12 & 7.53 & 7.45 \\
\hline
\end{tabular}




\subsection{Hypothesis testing}

For $\mathrm{H} 1, \mathrm{H} 2$ and $\mathrm{H} 3$ hypothesis confirmation, datas obtained from cluster analysis will be used, that is the information regarding beer consumption in three clusters.

H1: Most of beer is consumed from sport-entertainment oriented consumers; was rejected since from the information obtained in cluster analysis, this group consumes less amount of beer comparing with two other clusters. Weekly average amount in this group is 2.94 bottles of 0.5 litre that is 11.15 bottles of 0.5 litre, an amount that is less than two other groups. From this given information the hypothesis is rejected and is not accepted as true.

H2: Women beer consumers mostly belong to the segment of entertainment- sports oriented consumers. Also for confirmation of this hypothesis we use the information obtained from cluster analysis that is cluster profile information by demographic features, where it can be seen that percentage of female gender at sport-entertainment cluster makes $32.4 \%$, whereas at traditional-family cluster makes $11.8 \%$, and percentage is $12.5 \%$ at safety-health cluster. Therefore from this information veracity of this hypothesis can be completely accepted as true.

H3: Consumers belonging to traditional-family oriented segment mostly consume beer at home near their families. For confirmation of this hypothesis we use data given from cluster profiles based on beer consumption; where we can see that consumers of traditional-family segment mostly consume beer with friends making $82.4 \%$; also from this data we reject this hypothesis as untrue. However, when we talk about beer consumption with family the traditional-family cluster makes the highest percentage of $17.6 \%$ versus entertainment-sport clusters with $5.9 \%$ and safety-health with $7.5 \%$. But despite this fact the veracity of the hypothesis is rejected.

Independent Sample T-test and One-way between Groups Anova were used for for $\mathrm{H} 4$ and $\mathrm{H} 5$ hypothesis confirmation; in order to test the impact of two demographic characteristics of respondent lifestyle. Independent Sample T-test and One-way between Groups Anova were conducted with factors obtained from factor analysis as dependent variables and demographic characteristics as independent variables.

Indepedent Sample T-test is used to test the gender effects on beer consumer lifestyle factors. The proposed hypothesis is as follows:

H4: There are differences in the beer consumer lifestyles depending on gender.

Test results show that only 6 out of 16 factor issues used are statistically important $(\mathrm{p}<0.05)$.The following table shows male and female preferences from submitted factors by comparing results of the average column (Mean). However, on the other 10 cases no significant differences were found $(\mathrm{p}<0.05)$ which leads to the conclusion that H4 hypothesis is partially accepted as true. Below through the following table we present comparision of beer consumer lifestyle factors based on genders

Table 3.5 Indepedent Sample T-test results

\begin{tabular}{lllllllll}
\hline \multirow{2}{*}{ Factors } & \multicolumn{2}{c}{ Male } & \multicolumn{9}{c}{ Female } & & \\
\cline { 2 - 6 } & $\mathrm{N}$ & Average & $\mathrm{DS}$ & $\mathrm{N}$ & Average & $\mathrm{DS}$ & $\mathrm{t}(\mathrm{df})$ & significant \\
\hline Consumption, last week & 146 & 1.11 & 0.843 & 36 & 0.67 & 0.594 & $2.101(89)$ & 0.329
\end{tabular}




\begin{tabular}{|c|c|c|c|c|c|c|c|c|}
\hline $\begin{array}{l}\text { Consumption,last } \\
\text { month }\end{array}$ & 146 & 1.81 & 0.908 & 36 & 1.22 & 0.647 & $2.577(89)$ & $0.001 *$ \\
\hline Do you drink beer & 146 & 0.42 & 0.498 & 36 & 0.22 & 0.428 & $1.586(89)$ & $0.000^{*}$ \\
\hline \multicolumn{9}{|l|}{ At home } \\
\hline Season when you & 146 & 2.26 & 1.509 & 36 & 2.44 & 1.423 & -0.469 & 0.339 \\
\hline drink most & 146 & 0.08 & 0.277 & 36 & 0.5 & 0.514 & -4.735 & $0.000^{*}$ \\
\hline \multicolumn{9}{|l|}{ Preferred wrapping } \\
\hline $\begin{array}{l}\text { What beer you use } \\
\text { at home }\end{array}$ & 146 & 0.84 & 0.834 & 36 & 0.78 & 0.732 & $.270(89)$ & 0.214 \\
\hline How strong you like & 146 & 1.89 & 0.718 & 36 & 1.72 & 0.461 & $0.945(89)$ & 0.566 \\
\hline your beer & 146 & 2.08 & 1.233 & 36 & 2.33 & 0.97 & -0.804 & $0.005^{*}$ \\
\hline \multicolumn{9}{|l|}{ Your hobby } \\
\hline $\begin{array}{l}\text { Most important } \\
\text { things }\end{array}$ & 146 & 2.14 & 1.71 & 36 & 1.17 & 1.505 & $2.204(89)$ & 0.939 \\
\hline $\begin{array}{l}\text { Sense of } \\
\text { belonging }\end{array}$ & 146 & 7.63 & 0.858 & 36 & 7.33 & 0.485 & $1.409(89)$ & $0.022^{*}$ \\
\hline Warm & 146 & 7.56 & 0.577 & 36 & 7.33 & 0.594 & $1.495(89)$ & 0.772 \\
\hline \multicolumn{9}{|l|}{ Relationship } \\
\hline Self- & 146 & 7.05 & 0.762 & 36 & 7.5 & 0.514 & -2.346 & 0.864 \\
\hline $\begin{array}{l}\text { Fulfillment } \\
\text { To be }\end{array}$ & 146 & 7.86 & 0.652 & 36 & 7.89 & 0.323 & -0.163 & $0.005^{*}$ \\
\hline Respected & 146 & 8.16 & 0.646 & 36 & 8.11 & 0.832 & $.295(89)$ & 0.083 \\
\hline Safety & 146 & 7.38 & 0.543 & 36 & 7.44 & 0.511 & -0.43 & 0.999 \\
\hline $\begin{array}{l}\text { Selfrespect } \\
\text { Sense of }\end{array}$ & \multicolumn{2}{|c|}{ Selfrespect } & 0.651 & & 7.61 & 0.502 & -2.049 & 0.306 \\
\hline achievement & & & & & & & & \\
\hline
\end{tabular}

*important at $\mathrm{p}<0.05$

One-way between Groups Anova was conducted to see the impact of age on beer consumer lifestyle. The proposed hypothesis was:

H5: There are differences on beer consumer lifestyles depending on age.

One-way between Groups Anova has shown significant differences on eight factor issues across age groups $(\mathrm{p}<0: 05$, which can be seen in the table).

However here at other selected factors issues, no significant differences were found; therefore this hypothesis is only partially accepted as true. . 
Table no.3.6 One way Between Groups Anova test results

\begin{tabular}{|c|c|c|c|c|c|c|c|c|c|c|c|c|c|c|}
\hline \multirow[t]{3}{*}{ Factors } & \multicolumn{3}{|c|}{ Age $18-25$ yrs } & \multicolumn{3}{|c|}{ Age $26-35$ yrs } & \multicolumn{3}{|c|}{ Age $36-45$ yrs } & \multicolumn{3}{|c|}{ Age $45+$} & \multirow[b]{3}{*}{$\mathrm{F}(\mathrm{DF})$} & \multirow[b]{3}{*}{ Sig. } \\
\hline & & Aver & & & $\mathrm{Av}$ & & & $\mathrm{Av}$ & & & $\mathrm{Av}$ & $\mathrm{D}$ & & \\
\hline & $\mathrm{N}$ & age & DS & $\mathrm{N}$ & er. & DS & $\mathrm{N}$ & er. & DS & $\mathrm{N}$ & er. & S & & \\
\hline \multicolumn{15}{|l|}{ Amount last } \\
\hline & 6 & & 0.6 & 3 & 1.3 & 0.5 & 4 & 1.1 & 0.9 & 3 & 1.0 & 0.9 & 3.551( & 0.01 \\
\hline \multirow{2}{*}{$\begin{array}{l}\text { Week } \\
\text { Consumption, } \\
\text { last }\end{array}$} & 2 & 0.68 & 53 & 8 & 7 & 97 & 4 & 8 & 07 & 8 & 5 & 7 & 3) & $8^{*}$ \\
\hline & 6 & & 0.7 & 3 & & 0.8 & 4 & 1.9 & 0.9 & 3 & 1.6 & & 3.109( & 0.03 \\
\hline \multirow{2}{*}{$\begin{array}{l}\text { Month } \\
\text { Do you drink } \\
\text { beer }\end{array}$} & 2 & 1.35 & 55 & 8 & 2 & 82 & 4 & 5 & 5 & 8 & 3 & 0.9 & 3) & $1 *$ \\
\hline & 6 & & 0.4 & 3 & 0.4 & 0.5 & 4 & 0.4 & 0.5 & 1 & 0.2 & 0.4 & $.567(3$ & 0.63 \\
\hline \multirow{2}{*}{$\begin{array}{l}\text { at home } \\
\text { Season when } \\
\text { you }\end{array}$} & 2 & 0.39 & 95 & 8 & 2 & 07 & 4 & 5 & 10 & 9 & 6 & 5 & ) & 8 \\
\hline & 6 & & 1.5 & 3 & 2.4 & 1.5 & 4 & 1.9 & 1.4 & 3 & 1.8 & 1.2 & 1.654( & 0.18 \\
\hline drink most & 2 & 2.68 & 58 & 8 & 7 & 04 & 4 & 5 & 95 & 8 & 9 & 4 & & 3 \\
\hline Preferred & 6 & & 0.4 & 3 & 0.0 & 0.0 & 4 & 0.1 & 0.3 & 3 & 0.2 & 0.4 & 2.093( & 0.10 \\
\hline \multirow{3}{*}{$\begin{array}{l}\text { wrapping } \\
\text { What beer you } \\
\text { use }\end{array}$} & 2 & 0.26 & 45 & 8 & 0 & 00 & 4 & 4 & 51 & 8 & 1 & 2 & 3) & 7 \\
\hline & & & & & & & & & & & & & & \\
\hline & 6 & & 0.8 & 3 & 0.6 & 0.8 & 4 & 0.6 & 0.7 & 3 & 0.7 & 0.7 & $.988(3$ & 0.21 \\
\hline \multirow{2}{*}{$\begin{array}{l}\text { at home } \\
\text { How strong } \\
\text { you like }\end{array}$} & 2 & 1.06 & 14 & 8 & 3 & 31 & 4 & 8 & 80 & 8 & 9 & 9 & ) & 3 \\
\hline & 6 & & 0.6 & 3 & 2.0 & 0.7 & 4 & 1.8 & 0.4 & 3 & 1.8 & 0.8 & $.434(3$ & 0.72 \\
\hline \multirow[t]{2}{*}{ your beer } & 2 & 1.77 & 69 & 8 & 0 & 45 & 4 & 6 & 68 & 8 & 4 & 3 & & 9 \\
\hline & 6 & & 0.9 & 3 & 1.7 & 1.1 & 4 & 2.7 & 1.3 & 3 & 2.5 & & 6.591( & 0.00 \\
\hline \multirow{2}{*}{$\begin{array}{l}\text { Your hobby } \\
\text { Most } \\
\text { important }\end{array}$} & 2 & 1.61 & 19 & 8 & 9 & 82 & 4 & 7 & 43 & 8 & 8 & 0.9 & 3) & $0^{*}$ \\
\hline & 6 & & 0.9 & 3 & 2.3 & 1.6 & 4 & 2.9 & 0.7 & 3 & 3.1 & 1.5 & 31.070 & 0.00 \\
\hline \multirow{2}{*}{$\begin{array}{l}\text { things } \\
\text { Sense of }\end{array}$} & 2 & 0.29 & 02 & 8 & 2 & 00 & 4 & 1 & 5 & 8 & 6 & 7 & (3) & $0^{*}$ \\
\hline & 6 & & 0.6 & 3 & 7.7 & 0.6 & 4 & 7.9 & 0.5 & 3 & 8.1 & 0.6 & 20.843 & 0.00 \\
\hline \multirow{2}{*}{$\begin{array}{l}\text { belonging } \\
\text { Warm }\end{array}$} & 2 & 6.87 & 19 & 8 & 4 & 53 & 4 & 5 & 75 & 8 & 1 & 6 & & $0^{*}$ \\
\hline & 6 & & 0.5 & 3 & 7.4 & 0.5 & 4 & 7.7 & 0.5 & 3 & 7.7 & 0.5 & 6.538( & 0.00 \\
\hline \multirow{2}{*}{$\begin{array}{l}\text { Relationship } \\
\text { Self- }\end{array}$} & 2 & 7.23 & 6 & 8 & 2 & 07 & 4 & 7 & 28 & 8 & 9 & 4 & & $0^{*}$ \\
\hline & 6 & & 0.7 & 3 & 7.1 & 0. & 4 & 7.2 & & 3 & 7.3 & 0.8 & & 0.21 \\
\hline \multirow{2}{*}{$\begin{array}{l}\text { Fulfillment } \\
\text { To be }\end{array}$} & 2 & 6.94 & 27 & 8 & 6 & 65 & 4 & 3 & 12 & 8 & 7 & 3 & 3) & 3 \\
\hline & 6 & & 0.6 & 3 & 7.6 & 0.5 & 4 & 7.9 & 0.3 & 3 & 8.3 & 0.5 & 6.798( & 0.00 \\
\hline respected & 2 & 7.65 & 08 & 8 & 8 & 82 & 4 & 5 & 75 & 8 & 2 & 8 & & $0^{*}$ \\
\hline Safety/Securit & 6 & & 0.5 & 3 & 2.3 & 0.8 & 4 & 8.6 & 0.4 & 3 & 8.1 & 0.3 & 11.876 & 0.00 \\
\hline \multirow[t]{2}{*}{ y } & 2 & 7.71 & 88 & 8 & 7 & 31 & 4 & 4 & 92 & 8 & 1 & 2 & & $0^{*}$ \\
\hline & 6 & & 0.4 & 3 & 7.4 & 0.5 & 4 & 7.5 & 0.5 & 3 & 7.5 & 0.6 & 2.650( & 0.05 \\
\hline \multirow{2}{*}{$\begin{array}{l}\text { Selfrespect } \\
\text { Sense of }\end{array}$} & 2 & 7.19 & 02 & 8 & 2 & 07 & 4 & 0 & 98 & 8 & 8 & 1 & 3) & 4 \\
\hline & 6 & & 0.5 & 3 & 7.3 & 0.6 & 4 & 7.4 & 0.6 & 3 & 7.4 & & $.701(3$ & 0.55 \\
\hline achievement & 2 & 7.23 & 6 & 8 & 2 & 71 & 4 & 1 & 66 & 8 & 7 & 0.7 & ) & 4 \\
\hline
\end{tabular}


*Important at $p<0.05$

\subsection{Conclusions, Implications of the Study, the Limitations and Suggestions for Future Studies}

\subsection{Conclusions}

Through a series of analysis we have achieved through cluster analysis to group customers into three lifestyle segments, and they are entertainment-sport oriented segment, traditional-family oriented segment and health-safety oriented segment.

By grouping customers into three lifestyle segments we have provided answers to our main goal which has been segmenting beer customers according to lifestyles. With these practical results of the study we have concluded that beer consumers can be segmented according to existing lifestyles by supporting the conclusion of the existing theory that every industry needs its own instruments to conduct researches for lifestyle .

\subsection{Study implications}

Results from this study can help the beer industry in establishing marketing strategies by providing a clear picture of segmented groups. Having submitted our main goal that was to identify the beer consumer lifestyles, we noted that identifying lifestyles provides a good analytical basis for beer market segmentation, better positioning of the product on the market and more effective advertising.

a) Study implications on beer market segmentation: from study conclusions we can see that beer consumers can be segmented in three lifestyle groups. This research and division of segments by the lifestyle can serve marketers working in beer industry, in order to ensure a high degree of customer satisfaction and thus maintaining their loyalty to a certain brand of product. By having knowledge about each segment separately we acquire abundant knowledge about demographic data, and all the issues regarding beer consumption, hobbies and values. From these obtained data about lifestyle segments the production or marketing of this product can be oriented.

b) Study Implications on the positioning of the product: the objective in this study was to provide a useful information for positioning of the product in the market while exploring lifestyles as one of variables for segmentation. If the company manages to segmentize the whole market in three suggested segments and adjust production based on consumer lifestyle requirements, then the company product will be more accepted from consumers and will be successfully positioned in the market. Good market positioning of the product is the most important stage for enterprises, therefore selected marketing strategies play an essential role and are also one of the lifestyle segmentation strategies that is offered through this paper.

c) Study implications in advertisement: one of the four main forms of promotion by which the company is served to provide compelling information to potential buyers and public is advertising. By having knowledge over entertainment-sports lifestyle segment, traditional-family segment, and safety-health segment it is possible to conceive the product advertisement by this principle enabling better communication with consumer. By making advertisement that in itself contain information about lifestyle, the company 
manages to coordinate its interest with consumer's interest and as a result we meet consumer needs and achieve company objectives...

\subsection{Study limitations}

Main limitations can be summarized in two issues; responders number or sample's size and study instrument construction.

In order to accomplish the study we surveyed 182 responders beer consumers. Therefore small number of responders represents the main constraint of the study and its applicability since it can not represent the entire population of Kosovo broadly, despite efforts for a right inclusion.

Another constraint of the study relates to the construction of the survey instrument, where the scales used are not uniform. Some of the issues are on Likert's nine-point scale, most of questions are closed and one question is open.These varying scales/degrees are used because of the different references used for study question in questionnaire.

\subsection{Suggestions for future studies.}

Future research in this area should include various issues that are not included in this study.It is suggested that study instrument should include more issues/cases, similar to VALS or AIO instrument and responders number should not be under 1000 . This is because the more cases/issues are to be adressed and the more responders are to be interviewed the results are more accurate and their application in practice is easier and more effective.

Also it is suggested to carry out a general information of lifestyle in Kosova, from which later on data will derive easier for each industry separately.

\section{References}

Encyclopaedia of Marketing Research,1998 ,published by Ranjan Rajane.

Kottler Philip, Armstrong Gary, 2001. Principles of Marketing

Kottler Philip,Keller Kevin Lane,2006,Marketing Management 12thedition

Hoek Janet, Kearns Zane and Clearwater David, Massey University Psychographics: Segment Descriptions vs Segment Behaviours.

Wells D.William, Psychographics: A Critical Review,Journal of Marketing Research, Vol. 12, No. 2. (May, 1975), pp. 196-213.

Todd Sarah, Lawson Rob \& Faris Fiona ,A Lifestyle Analysis of New Zealand Consumers; Department of Marketing, University of Otago, PO Box 56, Dune din

Joan L. Walker \& Jieping Li ,Latent lifestyle preferences and household location decisions;

Published online: 26 September 2006_Springer-Verlag 2006

Rexha Nexhmi, Reshidi Nail, 1998, Marketing bases.

Pettigrew .Simone, King or Pawn? The role of the Australian Beer Drinker, published in "Journal of research for Consumer",2001.

Goldberg.M Stephen (1982) "An empirical study of lifestyle correlates to brand loyal behavior" - Advance in Consumer Research volume 9,1982 pages 456 deri 460.

Beatty, S.E., Kahle, L.R., Homer, P., \& Misra, S. (1985). Alternative measurement approaches to consumer values: the list of values and the Rokeach value survey.Psychology \& Marketing, 2(3), 181-200. 
Boote, A.S. (1981). Market segmentation by personal values and salient product attributes. Journal of Advertising Research, 27(1), 29-35.

Chaney, D. (1996). Lifestyles. New York: Routiedge.

Goldsmith, R.E., Stith, M.T. \& White, J.D. (1987).The Rokeach value survey and social desirability. The Journal of Social Psychology, 727(Oct.), 553-554.

Horley, J., Carroll, B., \& Littie, B.R. (1988). A typology of lifestyles. Social Indicator Research. 20, 383-398.

Maslow, A.H. (1954). Motivation and personality. New York: Harper.

Mitchell, A. (1983). The nine American lifestyles. New York: Macmillan Publishing Co.,Inc.

Novak, T.P., \& Macevoy, B. (1990). On comparing alternative segmentation schemes:the list of value (LOV) and values and lifestyle (VALS). Journal of Consumer Research, 77(Jun.), 105-109.

Pitts, R.E., \& Woodside, A.G. (1984). Personal values and consumer psychology.Lexington, MA: Lexington Books.

Plummer, J.T. (1974). The concept and application of life style segmentation. Journal of Marketing, 55(Jan.), $33-$

Rokeach, M. (1973). The nature of human values. Neë York: The Free Press.

Kahle, L.R. (2000). Cross-national consumer psychographics. Binghamton, NY: International Business Press.

Kahle, L.R., Beatty, S.E., \& Homer, P. (1986). Alternative measurement approaches to consumer values: the list of values (LOV) and values and life style (VALS). Journal of Consumer Research, 13(Dec.), 405-409.

Kahle, L.R. \& Kennedy, P. (1989). Using the list of values (LOV) to understand consumers. The Journal of Consumer Marketing, 6(3), 5-12.

Wells, W.D., \& Tigert, D.J. (1971). Activities, interests and opinions. Journal of Advertising Research ,77(Aug.), 27-

Wells, W.D. (1974). Life style and psychographic. Chicago: American Marketing Association.

Schreiber, A.L., \& Lenson, B. (1996). Lifestyle and event marketing: building the new consumer partnership. New York: McGraw-Hill, Inc.

Novak, T.P., \& Macevoy, B. (1990). On comparing alternative segmentation schemes: the list of value (LOV) and values and lifestyle (VALS). Journal of Consumer Research, 77(Jun.), 105-109.

Krishnan,J.(2002). Lifestyle Analysis - A Tool for Understanding Buyer Behaviour 